Research.

\title{
The effect of students' knowledge at the accounting department upon the interest of working as an accountant in a company
}

\author{
Rizki Ahmad Fauzi \\ Department of Accounting, Universitas Binaniaga Indonesia, Bogor, Indonesia \\ hafari3327@gmail.com (R. Ahmad Fauzi)
}

Received: March 12, 2020; Accepted: April 7, 2020; Published: June 30, 2020.

To cite this article: Fauzi, Rizki Ahmad. (2020). The effect of students' knowledge at the accounting department upon the interest of working as an accountant in a company. The Accounting Journal of BINANIAGA. 5 (1): 0108. doi: $\underline{10.33062 / a j b . v 5 i 01.363}$

\begin{abstract}
Choice in career is a process in choosing a job for his life. One career field that has a high chance is to be an accountant in a company. There are several things that can influence a person's decision in choosing a career. This study aims to determine the effect of knowledge of accounting department students on work interest in becoming an accountant in a company. This type of research is quantitative research with the expost facto method. Data was collected by distributing questionnaires to respondents. The population of this study was accounting students at the Diploma program at STIE Binaniaga. The method used to determine the sample is the purposive sampling method. Data analysis was carried out using a simple linear regression method. The results of this study indicate that there is an influence of knowledge on the interest in becoming an accountant in the company.
\end{abstract}

Keywords: Accountant, Interest, Knowledge

\section{INTRODUCTION}

Career planning is the most important thing to do to reach the career success, however, most people do not have good career planning due to uncertainty career in the future. Limited opportunity and chance have made people afraid of making a planning about what kind of job is to be chosen and taken. Someone's job is influenced by his / her intention. If someone who is interested in a job, he / she will try very hard to get it. This kind of job is his / her ideal based on his / her interest. Accountancy department is one department which is most students are interested in. It is identified by total of the students who are choosing this department, and it has explained that accountancy has taken special place to choose, nevertheless, it has been proven by the research mentioning that on average the students who have choosen this department have been driven by their interest to be a professional one in the accountancy (Anggara 2014).

The accountancy students who have finished their study can choose alternative ways on their career. First, they are who have finished their study at accountancy diplome can work directly in a company or such. Job opportunities that are available for them are varied, such as entrepreneurs (as the manager of their own business). For the people who are choosing to be an accountant in a company should have to continue their study at the Accountant Profession Education to get Accountant Degree. In general, the interest of the students is to be professional in the accountancy. Accountant job that can be done by the one who graduated from Accountancy is to be an accountant in a company. According to the main report on the webs of Indonesia Accountant Association (IAI) $17^{\text {th }}$ edition, Accountant profesion has been becoming more important in the recent

Rizki Ahmad Fauzi. The effect of students' knowledge at the accounting department upon the interest of working as an accountant in a company 
national economy since Indonesia has started implementing the International Financial Reporting Standard (IFRS) in 2012.

However, since the education, total and competency of the Indonesian Accountant are still limited comparing to other countries such as Malaysia which is having 2.000 accountants, Thailand is having 6.000 and Philipines 4.941, so that, it has explained that the condition of accountant profession in Indonesia is still required to be improved either the total of accountant or their competency. However, the competition of accountant service in Indonesia is still quite low, as, there are still less intention of the accountancy students to be an accountant as well as less total of accountants in Indonesia, but, in the meantime, the requirement of the improvement of accountant professionalism is obviously required. Nevertheless, it has motivated the writer to execute a writing about students' intention to choose the career as an accountant in the company.

\section{IDENTIFICATION OF THE PROBLEM}

Based on the background described above, the identifaction are as the following:

1. To what extent is the knowledge of the accountancy students about Accountant Profession?

2. To what extent is the intention of the accountancy students who want to be an accountant in a company?

3. To what extent is the effect of knowledge of accountancy students upon the intention to be an accountant in a company?

\section{PROBLEM LIMITATION}

Referring to the problem identification above, this research is limited only about the knowledge of accountancy students upon their intention to become an accountant in a company.

\section{PROBLEM DESIGN}

Problem design of this research is to find out the extent to which the knowledge of accountancy students has affected the intention to be an accountant in a company.

\section{AIMS OF THE RESEARCH}

Aims of this research are as the following:

1. To figure out the extent to which the knowledge of accountancy students understands about the accountant profession.

2. To figure out the extent to which the intention of the students who wants to be the accountant of a company is.

3. To measure the effect of knowledge of accountancy students upon the intention of being an accountant in a company.

\section{LIBRARY REVIEW}

\section{Knowledge}

Knowledge is an information or descripion that is recognized or realized by the people. Quality of the people is connected obviously with the quality of education which is obviously a chain of knowledge that has been studied by the people from elementary school, high school and university. The knowledge provided at the college of

Rizki Ahmad Fauzi. The effect of students' knowledge at the accounting department upon the interest of working as an accountant in a company 
accountancy department has concentrated only about the understanding of accountancy subjects based on the connection between theories and the application of the theories in a daily practicing that will produce a diploma degree graduate who is having high intellectual competency to be able to think critically and creatively. Basic Accountancy knowledge of the students provides the possibility to make the students develop themself and to produce their independency which is as the driving tools to enrich more accountancy sciences (Linda and Iskandar, 2014).

Knowledge is an ability to create model of mental describing an object precisely and to represent it as an action performed upon the related object (Kusrini, Martin \& Oxman, 2013) Knowledge is the result of know-how that will happen after the people using their feeling upon a certain object thru human senses such as see, hear, smell, sense and touch that mostly is received by the eyes and ears. The knowledge that is obtained by the students in this research is coming from their study during the period of their education.

\section{Intention}

Intention is a kind of being interested in something/some activities regardless of being requested or coming up suddenly or spontaneously but it is appearing due to the result of participation, knowledge and habit, Rachel Chrisanty (2013). Intention is defined as a condition happened due to happiness connected with self requirement or willingness. Intention is considered as an intermediary of motivational factors affecting the behavior, Mahmud (2014). According to Bahasa Indonesia Dictionary, intention is an attention, fondness of something along with willingness. Intention and attitude are important to make a decision. Intention can make someone perform something that he / she is interested in.

According to Slameto (2010) intention is a feeling of interesting for something or a certain activity without being asked for or ordered by. Basically, intention is the acceptance of a relationship between him / herself with others / things. The stronger / closer the relationship, the bigger the intention of someone is happened upon it. Intention is not attached when he / she was born, but it has been gotten after all. The intention and career planning of the accountancy students will give benefit mostly for the academic in designing a curriculum and lecturing process to be more effective which is in line with the students' profesion picked up (Kuningsih, 2013).

\section{Accountant Profession}

Accountant is an accountant which has gotten a license from the Ministry of Monetary to provide accountant service in Indonesia. Establishment and development of accountant profession in a country is getting along with the development of varied companies and legal institutions in the related country. Companies need capital / finance to run their business. This capital can come from internal company (owner) and external company (investor and loan from creditor). Therefore, financial report is required by both parties to make any decision related to their company. Financial report that will be prepared by the management is the information about the responsibility of finance management which is coming from external and internal company (Dwi, 2012).

\section{RESEARCH METHOD}

This research has applied quantitative approach using ex Post Facto. Variables of this research are the intention of students to be an accountant in a company.

\section{Place and Time of the Research} Bogor.

This research has taken place in September-December 2018 at STIE Binaniaga,

Rizki Ahmad Fauzi. The effect of students' knowledge at the accounting department upon the interest of working as an accountant in a company 


\section{Data Collection Technique}

Data Collection Technique has applied survey technique using the questionnaire about students' perception and questionnaire about the students' intention to become an accountant in a company.

\section{Population and Sample}

Target of the population of this research is all the active students of Accountancy department at STIE Binaniaga year of 2018. Sampling technique is applied purposive sampling which is the samples are active students year of 2018 (semester $5^{\text {th }}$ ).

\section{Data Analysis}

1. Requirement Test

a. Normality Test

Available normal or hardly normal data distribution will produce regression model that is applicable in a research (Nugroho, 2011). This research has applied Kolmogorov Smirnov Data that will be normal distribution if $\mathrm{Sig}>0.5$.

b. Autocorrelation Test

This test is to be done to figure out whether or not there is a correlation between error-term in the data. In order to find out whether or not there is autocorrelation occurred, and to see whether there is a correlation at every observation happened, it is mentioned on the value of DurbinWatson (DW) on the table of summary model (Sulaiman, 2014). Autocorrelation will not happen if $\mathrm{du}<\mathrm{DW}<$ (4-du).

c. Multicolinearity Test

Multicolinearity detection of this research has applied tolerance VIF with the requirement of Variance Inflation Factor $(\mathrm{VIF})<10$ and tolerance value $(\mathrm{TOL})$ $>0.1$ explaining that this model is free from multicolinearity.

d. Heteroscedasticity Test

Heteroscedasticity test of this research has applied Glejser test that is going to regress the residual absolute value (AbsUi) against other independent variables using regression equation. If its significance is less than 0.05 , the regression model has encountered the problem of heteroscedasticity (Ghozali, 2010).

2. Hypothesis Test

a. Simple Linear Regression

The analysis of this research has applied simple linear regression method. Simple regression analysis is being used to find out the knowledge of Accountancy students $(X)$ against their interest to become an accountant in a company $(\mathrm{Y})$. In general, simple regression is determined as the following equation:

$\mathrm{Y}=\mathrm{a}+\mathrm{bX}$

which is:

$\mathrm{a}=$ Constant

$\mathrm{b}=$ Regression Coefficient

$\mathrm{Y}=$ Intention to be an Accountant in a company

$\mathrm{X}=$ Knowledge

Rizki Ahmad Fauzi. The effect of students' knowledge at the accounting department upon the interest of working as an accountant in a company 


\section{Statistics Hypotheses}

Statistics Hypotheses for this research are as the following:

$\mathrm{H}_{\mathrm{o}}$ : There is not any effect of Knowledge of Accountancy students upon the Intention to work as Accountant in a company.

$\mathrm{H}_{\mathrm{a}}$ : There is the effect of Knowledge of Accountancy Students upon the Intention to work as an Accountant in a Company.

\section{RESULT AND DESCRIPTION}

\section{Requirement Test}

Applying Kolmogorov Smirnov Test has obtained data of 0.052 value $(p>0.05)$ explaining that three data of independent variables have been distributed normally. And the hypotheses are as the following:

$\mathrm{H}_{\mathrm{o}}$ : Data distributed normally.

$\mathrm{H}_{\mathrm{a}}$ : Data distributed abnormally.

According to the result of the calculation, it has gained significance value of 0.052 $>0.05$ which has explained that $\mathrm{H}_{\mathrm{o}}$ is rejected and it means that the data distributed normally.

\section{Result of Analysis of Hypotheses using Simple Linear Regression t test}

This calculation has applied simple linear regression test, it is measuring the correlation between variables which is variable knowledge about accountant profession and the intention to become an accountant in a company, $t$ test is used to measure the effect of knowledge upon the intention to become an accountant in a company.

Is to test the effect of knowledge upon the intention to become accountant in a company, it has gained t test of $p$ value $<0.05(p=0.000)$. Since the value of $0.000<$ 0.005 , it has explained that $H_{0}$ is rejected, so that it is indicating that knowledge has affected the intention to become an accountant in a company.

Table 1. T test calculation

One-Sample Test

\begin{tabular}{|c|c|c|c|c|c|c|}
\hline & \multicolumn{6}{|c|}{ Test Value $=0$} \\
\hline & \multirow[t]{2}{*}{$\mathrm{t}$} & \multirow[t]{2}{*}{ Df } & \multirow[t]{2}{*}{$\begin{array}{l}\text { Sig. }(2- \\
\text { tailed) }\end{array}$} & \multirow[t]{2}{*}{$\begin{array}{c}\text { Mean } \\
\text { Difference }\end{array}$} & \multicolumn{2}{|c|}{$\begin{array}{c}95 \% \text { Confidence Interval } \\
\text { of the Difference }\end{array}$} \\
\hline & & & & & Lower & Upper \\
\hline Knowledge & 26.753 & 23 & .000 & 3.833 & 3.54 & 4.13 \\
\hline Intention & 31.812 & 23 & .000 & 3.667 & 3.43 & 3.91 \\
\hline
\end{tabular}

And the hypotheses are as the following:

$H_{0}$ : There is not any effect of the students' knowledge happened upon the Intention to work as an accountant in a company.

$\mathrm{H}_{\mathrm{a}}$ : There is the effect of the students' knowledge happened upon the intention to work as an accountant in a company.

The calculation has indicated that significance value of $0.000<0.5$ explaining that $\mathrm{H}_{\mathrm{o}}$ is rejected which is the students' knowledge has affected the intention to work as accountant in a company. Significance value of 0.000 has to get thru the correlation test using simple linear regression test, this test is to find out the correlation between variables within this research. This test is indicated on the following table:

Rizki Ahmad Fauzi. The effect of students' knowledge at the accounting department upon the interest of working as an accountant in a company 
The Accounting Journal of BINANIAGA Vol. 05, No. 01, June 2020

p-ISSN: 2527-4309, e-ISSN: 2580-1481

$5^{\text {th }}$ Accreditation Rating: January 14, 2019 - January 13, 2024

Table 2. Simple Regression Test

\begin{tabular}{|c|c|c|c|c|c|c|}
\hline \multicolumn{7}{|c|}{ Coefficients $^{a}$} \\
\hline \multirow{2}{*}{\multicolumn{2}{|c|}{ Model }} & \multicolumn{2}{|c|}{$\begin{array}{c}\text { Unstandardized } \\
\text { Coefficients }\end{array}$} & \multirow{2}{*}{$\begin{array}{c}\text { Standardized } \\
\text { Coefficients } \\
\text { Beta } \\
\end{array}$} & \multirow[t]{2}{*}{$\mathrm{t}$} & \multirow[t]{2}{*}{ Sig. } \\
\hline & & $\mathrm{B}$ & Std. Error & & & \\
\hline \multirow{2}{*}{1} & (Constant) & .882 & .561 & & 1.572 & .030 \\
\hline & Knowledge level & .118 & .144 & .171 & .816 & .023 \\
\hline
\end{tabular}

a. Dependent Variable: The Intention to be Accoutant Profession

The result above has indicated sig.value $(0.023)<$ sig. $(0.05)$ explaining that $\mathrm{H}_{\mathrm{o}}$ is rejected describing that variable of Knowledge has correlated with the intentention to become an accountant. The education of accountancy at the university aims to produce a graduate person to be an expert which is ready to deal with accountancy practicing and as an intellectual worker that can support other intellectual workers. All the graduates have prepared themselves by developing themselves continuously with their knowledge to anticipate any future changes. A career chosen is an individual process or activity to prepare himself / herself to start a career in the job thru a chain of activity process orderly and systematically (Dwi and Setiawan, 2012). Career chosen of the accountancy students is a starting up of career development after they finished their study. There are some challenges to be faced by the students choosing a career such as career uncertainty, information accessible and career development program, economical and technological challenges, as well as social and culture challenges.

In general, the intention of accountancy students is to become professional people in the accountancy. But, as a matter of fact, the capacity of accountant profession placement is not in the position to hire all the people graduated from the accountancy department since they are so many. Therefore, many of them are not working according to their education and degree. Actually, carreer selection has reflected a person's intention, personality, competency and background. People are looking for a career that can give them an opportunity to present their skills and competency and to actualize their attitude and value of live. They will feel suitable with their career, if it could cover all their willingness and comply with their own intention and capability. In general, the intention of students to select a career is influenced by their personal knowledge about the job environment, information received from the previous alumnus, family or relatives, lecturers, and text book they have read (Wany, 2011). In order to select a career, people are going to look for the information about some alternative professions and after all, they eager to know more whether such the profession is suitable for them or not (Dwi and Setiawan, 2012). Based on the research done by Rahayu, Sudaryono, and Setiawan about the knowledge of accountancy students regarding the factors influencing a career selection of the students who are in the third years of either state or private universities in Jakarta.

A career selected by accountancy students is the beginning of career development. After finishing their study at the university, the career for accountancy graduates is not only accountant profession, but also many profession can be chosen by them depending on their background. A career is an accumulation of knowledge reflected on skills, expertises and extensive network relationship. Job opportunities in business enterprises have provided some professions that can be selected by accountancy diploma. Rapid development of business in Indonesia recently has provided indirectly varied opportunities for the people who want to work. Accountancy graduates are considered a group of working people. The study of accountancy program is one program study that is very much intended by the students. On average the students who are selecting accountancy department due to their intention to become professional in accountancy. Getting along with it, developing business enterprises are requiring accountancy graduates who are qualified and ready to work. Nevertheless, the

Rizki Ahmad Fauzi. The effect of students' knowledge at the accounting department upon the interest of working as an accountant in a company

Page : 6 
education system has been designed to be in compliance with business enterprises requirement for accountancy diploma.

Accountant Profesion is a profesion as the communicator between management and the owner or the management that is governing the business unit. Main duty of accountant profession has focused in auditing or other task to give the opinion about the reliability of financial report made by the management. The opinion of accountant is applicable for the parties which are concerned about financial reporting either internal management of the company or external parties (investors, creditors, government and society) This profession has given an opportunity to get a challenging and varied job because the accountants can be placed at various location and companies which are having different condition.

This research is complied with the actual condition in the accountancy diplome STIE Binaniaga stated that working as an accountant in a company is mostly wanted, Result of $t$ test has indicated the accountancy knowledge has affected the intention of becoming an accountant. The students who are having good knowledge of accountancy will be eager to be an accountant in a company. However, the students who are not having sufficient knowledge about accountancy will not be eager to be an accountant in a company (Mahayani, 2017) Higher knowledge of the students has impacted good perception about accountant profession in a company which is more relevant rather than the perception of accountant as the reason for them to pursue a career as an accountant in a company (Putri, 2015).

Yusuf cited in Indrawati (2012) described that the quality of accountancy graduates refered to the implementation of accountancy diplome programe which has been applied so far, and it is still being questioned regarding the quality of the subjects being taught, more over, if they work for or establish a public accountant, since the graduates are considered beyond the requirement. The competency of graduates can be seen thru the curriculum and learning subjects given which is it should be in compliance with general international curriculum. Global certificate about general competency especially in Accountant Profesion is required to support the qualification requirement. Competency of an accountant graduated diplome is required in order to support the career asf an accountant. Most accountancy graduates do not have self-confidence to be an accountant, because they feel they do not have sufficient qualification, due to their knowledge obtained during their study. Nevertheless, for the students who have good knowledge or extensive knowledge about accountancy tend to have strong desire to be an accountant in a company.

\section{CONCLUSION AND SUGGESTIONS}

This reseach has indicated that the knowledge of accountancy has affected the intention to be an accountant in a company. The students who are having good knowledge about accountancy will be interested in working as an accountant in a company.

\section{REFFERENCE}

Arens, A. A., Elder, R. J., and Beasley, M. S. 2012. Auditing and Assurance Services: an Integrated Approach (14th ed.). Essex, England: Pearson Education, Inc.

Association of Certified Fraud Examiners (ACFE). 2010. Report to The National Asia Pasific (Online). http://www.ethicsline.com/pdf/2010-ACFEReport-to-NationsAsia-Pacific.pdf diakses pada tanggal 7 April 2013.

Rizki Ahmad Fauzi. The effect of students' knowledge at the accounting department upon the interest of working as an accountant in a company 
Black's Law Dictionary. 2012. What is FRAUD (Online). http://thelawdictionary.org/fraud/, diakses tanggal 25 November 2013.

Dwi, Christine dan Arif Setiawan. 2012. Pengaruh Persepsi Mahasiswa Akuntansi Mengenai Lingkungan Kerja Auditor terhadap Pilihan Karirnya Sebagai Auditor di KAP (Studi Kasus pada Mahasiswa Akuntansi Universitas Kristen Maranatha dan Universitas Parahyangan). Jurnal IImiah Akuntansi, Hal. 1-13. Bandung.

Ghozali, Imam. 2011. Ekonometrika: Teori, Konsep dan Aplikasi dengan SPSS 17. Semarang: Badan Penerbit Universitas Diponegoro.

Kuningsih, R. S. (2013). Faktor-Faktor yang Mempengaruhi Niat Mahasiswa untuk Berkarir sebagai Akuntan Profesional. Skripsi. Semarang: Universitas Diponegoro.

Linda, dan Iskandar Muda. 2014. Pengaruh Pengetahuan Akuntansi dan Motivasi terhadap Minat Mahasiswa dan Akuntansi Perguruan Tinggi Negeri dan Swasta di Propinsi Nanggroe Aceh Darussalam untuk Mengikuti Pendidikan Profesi Akuntansi (PPAK). Jurnal Keuangan dan Bisnis. 3 (2): 133-143.

Mahayani, Ni Made Dwi, Ni Luh Gede Eli Sulindawati, dan Nyoman Trisna Herawati. 2017. Pengaruh Persepsi, Motivasi, Minat, dan Pengetahuan Mahasiswa Akutansi Program S1 terhadap Pilihan Berkarier. Jurnal Akutansi Program S1. 7 (1): 1-11.

Nugroho, B. A. 2010. Strategi Jitu Memilih Metode Statistik Penulisan dengan SPSS. Yogyakarta: C.V. Andi Offset.

Nur Rochim Andrias, 2013. Pengaruh Motivasi terhadap Minat Mahasiswa Akuntansi untuk Mengikuti Pendidikan Profesi Akuntansi. (Studi pada Mahasiswa Akuntansi Program S1 dan Program PPAK Universitas Brawijaya). Skripsi. Fakultas Ekonomi Universitas Brawijaya.

Putri, Rahmalia Prima. 2015. Faktor-Faktor yang Mempengaruhi Minat Mahasiswa Jursuan Akutansi untuk Berkarier. Jom Fekon. 2 (1): 1-13.

Rachel Chrisanty, 2013. Pengaruh Faktor Eksternal dan Internal terhadap Pemilihan Karir Mahasiswa Akuntansi Sebagai Akuntan Publik. (Studi Empiris pada Mahasiswa Akuntansi Universitas Riau). Pekanbaru. Skripsi. Fakultas Ekonomi Universitas Riau.

Sari, Mega Diana. 2015. Pengaruh, Motivasi, Persepsi, dan Pertimbangan Pasar Kerja terhadap Mainat Mahasiswa PPAK dalam Pemilihan Karir Sebagai Akuntan Publik. Jom Fekon. 2 (2): 1-14.

Slameto. (2010). Belajar dan Faktor-Faktor yang Mempengaruhinya. Jakarta: Rineka Cipta.

Rizki Ahmad Fauzi. The effect of students' knowledge at the accounting department upon the interest of working as an accountant in a company 